\title{
Purification and Some Properties of Aspartate Aminotransferase of Methanobacterium thermoformicicum SF-4
}

\author{
Toshio Tanaka, Takeshi Tokuda, Akira TaChibana, \\ Makoto Taniguchi and Susumu OI \\ Department of Biology, Faculty of Science, Osaka City University, \\ Sugimoto 3-3-138. Sumiyoshi-ku, Osaka 558, Japan \\ Received September 4, 1989
}

\begin{abstract}
Aspartate aminotransferase (AAT) of Methanobacterium thermoformicicum SF-4 was purified to a homogeneous state on polyacrylamide gel electrophoresis (PAGE) by DEAE-cellulose, Polybuffer Exchanger (PBE), Phenyl-Sepharose, and hydroxyapatite column chromatography. The molecular weight of the enzyme was estimated to be 57,000 by both gel filtration and PAGE on a gradient gel. Subunit analysis by sodium dodecyl sulfate (SDS)-PAGE suggested its existence as a single polypeptide with a molecular weight of 50,000 . The enzyme showed its maximum activity at $60 \mathrm{C}$ and at $\mathrm{pH}$ 8.5. The activity did not decrease to any extent after heat treatment at $70 \mathrm{C}$ for $1 \mathrm{hr}$ at $\mathrm{pH} 7.5$. Transamination activity on L-glutamate was about 4 times higher than that on L-aspartate and was also observed weakly on L-cysteine. Maleate was the most effective inhibitor, while glutarate and fumarate were less effective inhibitors.
\end{abstract}

Aspartate aminotransferase (AAT) (EC 2.6.1.1) is one of the key enzymes in amino acid metabolism where it catalyzes transamination between L-aspartate and $\alpha$-ketoglutarate, giving rise to L-glutamate and oxaloacetate. The enzyme can effectively mediate a reverse reaction by transferring the amino group of L-glutamate to oxaloacetate. Rudman and Meister ${ }^{1)}$ first demonstrated the occurrence of microbial AAT in Escherichia coli $\mathrm{W}$ and since then purification and characterization of microbial AATs have been focused mainly on those of $E$. coli ${ }^{2-6}$ and Pseudomonas striata. ${ }^{7}$

In 1982, Kenealy et $a l^{81}$ showed the presence of AAT and glutamine synthetase in cellfree extracts of Methanobacterium barkeri and $M$. thermoautotrophicum at significant levels. This indicates that the most common pathways of ammonia assimilation and the following transamination in microbes are also functioning in methanogens. However, the above enzymes directly involved in the metabolism of L-glutamate and related amino acids have not been purified and characterized yet in methanogens, strictly anaerobic bacteria.
Recently, a formate-utilizing thermophilic methanogen was isolated and identified as Methanobacterium thermoformicicum SF-4. ${ }^{9)}$ We could also detect transamination activities between various amino acids and $x$-ketoglutarate in cell-free extracts of strain SF-4 even under aerobic conditions. Among them, the activity on L-aspartate was detected at the highest level, indicating the presence of AAT in this methanogen. The bacterial AAT could be purified and characterized by the usual chromatographic and assay procedures because of its aerotolerance. In this work, purification of AAT from strain SF-4 and some of its properties are described and compared with AATs of other microbial and mammalian origins.

\section{Materials and Methods}

Bacterial strain and growth conditions. Strain SF-4 was grown in a 5-1 jar fermentor with 31 of $\mathrm{S}$ medium under a continuous flow of $\mathrm{H}_{2}+\mathrm{CO}_{2}$ as described previously. ${ }^{91} \mathrm{At}$ the late logarithmic growth phase, half of the bacterial culture was withdrawn and anaerobically replaced with the same volume of newly prepared S medium. Such a semi-batch style cultivation was repeated several times for 
about 1 week. Cells of strain SF-4 were harvested by centrifugation and were kept at $-20^{\circ} \mathrm{C}$ as a suspension in $50 \mathrm{~mm}$ Tris- $\mathrm{HCl}$ buffer, $\mathrm{pH} \mathrm{7.0,} \mathrm{until} \mathrm{it} \mathrm{was} \mathrm{used} \mathrm{for} \mathrm{AAT}$ purification.

Preparation of crude extract. The bacterial cell $(6.7 \mathrm{~g}$, wet weight) suspension was disrupted by sonication 4 times with a Branson Sonifier B-12 for $30 \mathrm{sec}$. The supernatant obtained after centrifugation at $10,000 \mathrm{rpm}$ for 20 min was used as a crude AAT preparation.

Assay of $A A T$. Unless otherwise stated, AAT was assayed by the method of Reitman and Frankel ${ }^{10}$ with a little modification. Enzyme solution $(0.2 \mathrm{ml})$ was mixed with $1.0 \mathrm{ml}$ of standard substrate solution consisting of $100 \mathrm{~mm}$ Tris- $\mathrm{HCl}$ buffer, $\mathrm{pH} 7.5,50 \mathrm{~mm}$ L-aspartate, $5 \mathrm{~mm} x$-ketoglutarate, and $15 \mu \mathrm{M}$ pyridoxal phosphate (pyridoxal-P). After the mixture was incubated at $60^{\circ} \mathrm{C}$ for $20 \mathrm{~min}$, the reaction was stopped by addition of $1 \mathrm{ml}$ of I $\mathrm{mm}$ 2,4-dinitrophenylhydrazine in $2 \mathrm{~N} \mathrm{HCl}$, followed by incubation at room temperature for $20 \mathrm{~min}$. Pyruvate formed from oxaloacetate, which was a product of transamination by AAT, was measured as the increase in optical density at $505 \mathrm{~nm}$ due to formation of its 2,4-dinitrophenylhydrazone. Correction was always made for $x$-ketoglutarate being slightly positive in the reaction using the optical density of the mixture without enzyme as a blank. This assay procedure was useful in the range of pyruvate formation up to $0.25 \mu \mathrm{mol}$. One unit was defined as the amount of enzyme that catalyzed the formation of $1 \mu \mathrm{mol}$ of oxaloacetate (pyruvate) per $\min$ under the above condition.

Amino donor specificity was assayed by enzymic measurement of L-glutamate which was formed from various amino acids and $\alpha$-ketoglutarate as described below. After the standard substrate solution containing each of the L-amino acids was incubated at $60^{\circ} \mathrm{C}$ for $20 \mathrm{~min}$, the reaction was stopped by heating at $100 \mathrm{C}$ for $10 \mathrm{~min}$. To the supernatant obtained after removing denatured proteins by centrifugation were added $1.63 \mathrm{ml}$ of $100 \mathrm{~mm}$ Tris- $\mathrm{HCl}$ buffer, $\mathrm{pH} 7.5,100 \mu 1$ of $3 \mathrm{~mm}$ EDTA, $50 \mu \mathrm{l}$ of $35 \mathrm{~mm} \mathrm{NAD}$, and $20 \mu \mathrm{l}$ of L-glutamate dehydrogenase ( 390 units $/ \mathrm{ml}$ ). The amount of L-glutamate produced in the reaction was measured by the increase of optical density at $340 \mathrm{~nm}$ using a Shimadzu UV-260 spectrophotometer. One unit was defined as the amount of enzyme which produced $1 \mu \mathrm{mol}$ of L-glutamate under the above conditions. When L-glutamate was used as an amino donor, a solution containing $50 \mathrm{~mm}$ L-glutamate, $5 \mathrm{mM} \alpha$-ketoglutarate, $15 \mu \mathrm{M}$ pyridoxal-P, and $0.25 \mu \mathrm{Ci}$ of $\mathrm{L}-\left[\mathrm{U}-{ }^{14} \mathrm{C}\right] \mathrm{glutamic}$ acid $(250 \mathrm{mCl} / \mathrm{mmol})$ in a final volume of $100 \mu$ was mixed with $20 \mu \mathrm{l}$ of enzyme solution. The mixture was put on a column of Amberlite IR $120\left(\mathrm{H}^{+}\right)$ $(1.4 \times 4.0 \mathrm{~cm})$ to trap L-glutamate after incubation at $60^{\circ} \mathrm{C}$ for $20 \mathrm{~min}$. Then, the column was washed with distilled water. ${ }^{14} \mathrm{C}$-Labeled $\alpha$-ketoglutaric acid obtained in the eluate was counted in a Packard Tri-Carb 460 scintillation counter. The amount of L-glutamate formed in the reaction was measured as a corresponding amount of $\alpha$ ketoglutarate calculated on the basis of its radioactivity.

Amino acid analysis. The protein samples were hydrolyzed for 24,48 , and $72 \mathrm{hr}$ at $110^{\circ} \mathrm{C}$ with $6 \mathrm{~N} \mathrm{HCl}$ in a sealed tube. The amino acid composition was measured using a Hitachi amino acid autoanalyzer 835. The tryptophan content was spectrophotometrically measured by the method of Goodwin and Morton. ${ }^{11)}$

Electrophoresis. The purity of AAT was analyzed by polyacrylamide gel electrophoresis (PAGE) using both $7.5 \%$ and $12.5 \%$ polyacrylamide slab gels at $\mathrm{pH} 8.3$. The protein bands were stained with Coomassie Brilliant Blue. For detection of AAT activity, gel slices ( $5 \mathrm{~mm}$ in length) were cut from another lane with the same sample after electrophoresis and extracted with $0.2 \mathrm{ml}$ of $50 \mathrm{~mm}$ Tris$\mathrm{HCl}$ buffer, $\mathrm{pH} 7.5$, overnight at $4^{\circ} \mathrm{C}$. The enzyme activity in each extract was assayed using the standard substrate solution. Electrophoresis was also done on a $5-20 \%$ gradient gel at a constant current of $10 \mathrm{~mA}$ for $15 \mathrm{hr}$. Sodium dodecyl sulfate-polyacrylamide gel electrophoresis (SDS-PAGE) ${ }^{12)}$ was done on a $5 \%$ gel after treating the enzyme with $1 \% \operatorname{SDS}$ and $1 \% 2$-mercaptoethanol at $100^{\circ} \mathrm{C}$ for $1 \mathrm{~min}$.

Estimation of molecular weight. The molecular weight of native AAT was measured by PAGE on a gradient gel in addition to gel filtration on a column of Toyopearl HW-55 $\mathrm{F}(2.5 \times 59 \mathrm{~cm})$ equilibrated with $50 \mathrm{~mm}$ Tris- $\mathrm{HCl}$ buffer, pH 7.5 , containing $0.3 \mathrm{M} \mathrm{NaCl}$ and $15 \mu \mathrm{M}$ pyridoxal-P. The subunit structure of AAT was estimated by SDS-PAGE. Standard proteins used were as follows: bovine serum albumin $(67,000)$, hen egg albumin $(45,000)$, chymotrypsinogen $A(25,000)$, and cytochrome $c(12,500)$ for gel filtration; catalase $(232,000)$, lactate dehydrogenase $(140,000)$, bovine serum albumin $(67,000)$, and ovalbumin $(43,000)$ for PAGE; bovine serum albumin $(67,000)$, catalase $(60,000)$, lactate dehydrogenase $(36,000)$, and ferritin $(18,500)$ for SDS-PAGE.

Protein measurement. Protein was measured by the method of Bradford ${ }^{13)}$ with bovine serum albumin as a standard. In each chromatography step, the elution profile of protein was followed by measuring the absorbance at $280 \mathrm{~nm}$.

Reagents. DEAE-cellulose was obtained from Brown Co. Polybuffer Exchanger (PBE) 94 and Phenyl-Sepharose CL-4B were from Pharmacia. Hydroxyapatite was purchased from Seikagaku Kogyo Co., Tokyo, Japan. Toyopearl HW-55 F was from Toyo Soda Mfg., Co., Ltd., Tokyo, Japan. L-Glutamate dehydrogenase (beef liver) was obtained from Oriental Yeast Co. Standard proteins for molecular weight estimation were purchased from Boehringer and Pharmacia. L-[U- $\left.{ }^{14} \mathrm{C}\right]$ Glutamic acid 
( $250 \mathrm{mCi} / \mathrm{mmol}$ ) was a product of New England Nuclear. Other chemicals were of analytical reagent grade.

\section{Results}

\section{Aminotransferase activities in crude extract}

The aminotransferase activities of crude extract on various amino acids and $\alpha$-ketoglutarate as an amino acceptor are presented in Table I. Apparently, the highest transamination activity was observed on L-aspartate, but the enzyme preparation showed weak activities on L-isoleucine, L-leucine, L-valine, Lcysteine, L-methionine, L-alanine, and some aromatic and basic amino acids. This methanogen seemed to produce branched-chain amino acid aminotransferase (EC 2.6.1.42) and alanine aminotransferase (EC 2.6.1.2) as well as AAT.

\section{Purification of $A A T$}

AAT was purified from the crude extract of strain SF-4 as follows. The crude extract $(93 \mathrm{ml})$ was put on a column of DEAEcellulose $(3.7 \times 25 \mathrm{~cm})$ equilibrated with buffer A $(50 \mathrm{~mm}$ Tris- $\mathrm{HCl}$ buffer, $\mathrm{pH} 7.0)$. After washing the column with about $500 \mathrm{ml}$ of buffer $\mathrm{A}$, the enzyme was eluted with a linear gradient of sodium chloride $(0-1.0 \mathrm{M})$. Active fractions, which were eluted with about 0.4 $\mathrm{M}$ sodium chloride, were combined and dia-

Table I. Aminotransferase Activity in the Crude EXTRACT OF $M$. thermoformicicum SF-4

\begin{tabular}{lc} 
Amino acid & $\begin{array}{c}\text { Specific activity } \\
\text { (U/mg protein) }\end{array}$ \\
\hline L-Aspartate & 0.100 \\
L-Isoleucine & 0.019 \\
L-Leucine & 0.019 \\
L-Valine & 0.015 \\
L-Cysteine & 0.011 \\
L-Methionine & 0.011 \\
L-Alanine & 0.009 \\
L-Phenylalanine & 0.007 \\
L-Tryptophan & 0.004 \\
L-Lysine & 0.004 \\
L-Arginine & 0.003 \\
L-Asparagine & 0.002 \\
\hline
\end{tabular}

a Measured by L-glutamate formation. lyzed against buffer $\mathrm{A}$. The dialyzed solution was then put on a column of PBE 94 $(1.6 \times 13.6 \mathrm{~cm})$ equilibrated with buffer $\mathrm{A}$, and was eluted with a linear gradient of sodium chloride $(0-1.0 \mathrm{M})$ after washing the column with about $200 \mathrm{ml}$ of buffer A. Solid sodium chloride was added to a pool of active fractions, which were eluted with about $0.7 \mathrm{M}$ sodium chloride, at the final concentration of $1.0 \mathrm{M}$. Then the solution was chromatographed on a column of Phenyl-Sepharose CL-4B $(1.6 \times 4.6 \mathrm{~cm})$ equilibrated with buffer $\mathrm{A}$ containing $1.0 \mathrm{M}$ sodium chloride and $15 \mu \mathrm{M}$ pyridoxal-P. This hydrophobic chromatography could effectively remove most proteins in the pass-through fractions, while AAT activity was detected widely in fractions eluted with a decreasing concentration of sodium chloride $(1.0-0 \mathrm{M})$. In this gradient elution, the peak of AAT activity was observed in the fractions containing $0.17 \mathrm{M}$ sodium chloride. Analysis by PAGE, however, showed the presence of two major protein bands in the AAT preparation thus obtained. Active fractions were combined and dialyzed against buffer B (50 mm phosphate buffer, pH 7.0, containing $15 \mu \mathrm{M}$ pyridoxal-P). The inner solution was then put on a column of hydroxyapatite $(1.6 \times 2.8 \mathrm{~cm})$ equilibrated with buffer B. After eluting nonadsorbed proteins by washing the column with buffer B, AAT was eluted with $0.3 \mathrm{M}$ phosphate buffer, $\mathrm{pH} 7.0$, containing $15 \mu \mathrm{M}$ pyridoxal-P. Active fractions were pooled and used as purified AAT in the following experiments. The specific activity of AAT

Table II. Summary of Purification of AAT FROM $M$. thermoformicicum SF-4

\begin{tabular}{|c|c|c|c|c|c|}
\hline Step & $\begin{array}{c}\text { Volume } \\
(\mathrm{ml})\end{array}$ & $\begin{array}{l}\text { Total } \\
\text { activity } \\
\text { (U) }\end{array}$ & $\begin{array}{c}\text { Total } \\
\text { protein } \\
(\mathrm{mg})\end{array}$ & $\begin{array}{l}\text { Specific } \\
\text { activity } \\
(\mathrm{U} / \mathrm{mg})\end{array}$ & $\begin{array}{l}\text { Yield } \\
(\%)\end{array}$ \\
\hline $\begin{array}{l}\text { Crude extract } \\
\text { DEAE- }\end{array}$ & 93 & 89.2 & 919.5 & 0.10 & 100 \\
\hline cellulose & 172 & 63.2 & 298.0 & 0.21 & 70.8 \\
\hline PBE 94 & 62 & 45.8 & 26.5 & 1.73 & 51.3 \\
\hline \multicolumn{6}{|l|}{ Phenyl- } \\
\hline Sepharaose & 113 & 35.9 & 6.6 & 5.44 & 40.2 \\
\hline Hydroxyapatite & 31 & 32.9 & 3.9 & 8.44 & 36.9 \\
\hline
\end{tabular}


could be increased 84.4 -fold with the recovery yield of $36.9 \%$ during these purification processes, as summarized in Table II. The purified AAT could be stored without any loss of activity at $-20^{\circ} \mathrm{C}$ or $4^{\circ} \mathrm{C}$ for at least 2 weeks.

\section{General properties}

The purified enzyme preparation was detected as a single band on PAGE using $12.5 \%$ and $7.5 \%$ gels (Fig. 1). In each gel, AAT activity was exactly recovered in gel slices corresponding to the protein band. The molecular weight of native AAT was measured in two diffèrent ways, gel filtration and PAGE on a gradient gel, being estimated to be 57,000 by both methods. Analysis by SDS-PAGE gave a similar value $(50,000)$, suggesting that AAT of strain SF-4 had a monomeric structure with a single polypeptide.

The enzyme was active in the alkaline $\mathrm{pH}$ range of 7.0-11 and showed the maximum activity at around $\mathrm{pH} 8.5$. In heat treatment at

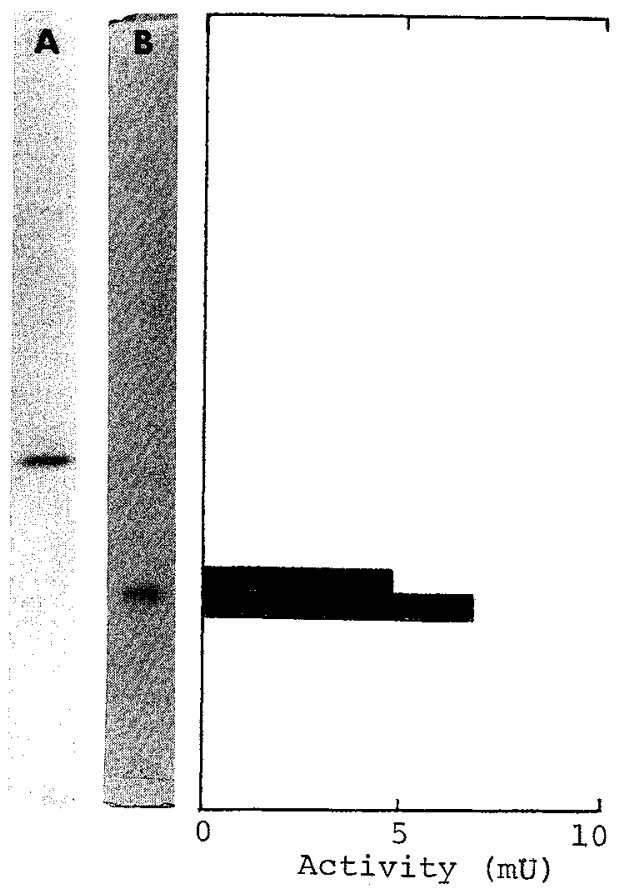

Fig. 1. Polyacrylamide Gel Electrophoresis of the Purified AAT on $12.5 \%$ (A) and $7.5 \%$ (B) Gel.

Closed bars indicate AAT activity detected in gel slices of $7.5 \%$ gel.
pH 7.5 for $1 \mathrm{hr}$, the enzyme was stable up to $70^{\circ} \mathrm{C}$. The optimum temperature was $60^{\circ} \mathrm{C}$.

The amino acid composition of AAT is shown in Table III. It was different in higher contents of glutamic acid, glycine, valine and isoleucine as well as in lower contents of methionine and tryptophan from those of $E$. coli $\mathrm{B}^{14)}$ and mammalian enzymes. ${ }^{15,16)}$

Requirements for cofactors were examined after completely removing exogenously added pyridoxal-P by repeated ultrafiltration. The enzyme showed the same activity when assayed using a standard substrate solution with or without pyridoxal-P, suggesting a tightly bound cofactor. The absorption spectrum gave characteristic maxima unusual for AAT at $274 \mathrm{~nm}(\varepsilon: 50,000)$, at $315 \mathrm{~nm}(\varepsilon: 8,300)$, and at $410 \mathrm{~nm}(\varepsilon: 3,300)$ at $\mathrm{pH} 8.0$. However, the presence of pyridoxal-P or its derivative was suggested according to similar absorption spectrum observed in mammalian aminotransferases ${ }^{17.18)}$ other than AAT. AAT of strain SF-4 did not show a clear $\mathrm{pH}$-dependent spec-

Table III. Amino Acid Composition of AAT of $M$. thermoformicicum SF-4

\begin{tabular}{lr} 
Amino acid & $\begin{array}{r}\text { Number per } \\
\text { mole of AAT }\end{array}$ \\
\hline Lysine & 23.7 \\
Histidine & 8.2 \\
Arginine & 20.7 \\
Aspartic acid & 50.3 \\
Threonine & 25.8 \\
Serine & 25.2 \\
Glutamic acid & 62.7 \\
Proline & 18.7 \\
Glycine & 41.9 \\
Alanine & 41.2 \\
Cysteine & 3.8 \\
Valine & 42.5 \\
Methionine & 1.9 \\
Isoleucine & 32.8 \\
Leucine & 42.6 \\
Tyrosine & 7.4 \\
Phenylalanine & 14.8 \\
Tryptophan & 1.9 \\
\hline The average or extrapolated (threonine and serine) & \\
value from 24, 48, and 72 hr hydrolysis. The molec- & \\
ular weight was assumed to be 50,000. \\
Measured spectrophotometrically.
\end{tabular}


trum shift at $\mathrm{pH} 6.0$.

\section{Substrate specificity}

The amino donor specificity of the enzyme was examined on the basis of L-glutamate formation from various amino acids and $\alpha$ ketoglutarate. As shown in Table IV, Lglutamate was the most effective substrate for the enzyme of strain SF-4 rather than Laspartate. The enzyme could apparently act on L-cysteine in addition to L-cysteinesulfinate,

Table IV. Amino DONOR SPECIFICITy OF AAT of $M$. thermoformicicum SF-4

\begin{tabular}{lc} 
Amino donor & $\begin{array}{c}\text { Relative activity } \\
(\%)\end{array}$ \\
\hline L-Glutamate & $100^{a}$ \\
L-Cysteine-sulfinate & 40.3 \\
L-Aspartate & 25.2 \\
L-Cysteine & 6.0 \\
L-Methionine & 1.0 \\
L-Phenylalanine & 1.0 \\
\hline
\end{tabular}

a Measured with radioactive L-glutamate. while the activity on the other amino acids other than L-methionine and L-phenylalanine were negligible.

\section{Inhibitors}

The effects of various carboxylic acids ${ }^{19)}$ on AAT of strain SF-4 were examined at the concentration of $40 \mathrm{~mm}$. Maleate, the most effective inhibitor of mammalian enzymes, also showed the maximum inhibition $(76 \%)$ for this bacterial enzyme. The enzyme was moderately inhibited by adipate at the extent of $65 \%$, showing the sensitivity similar to that of mammalian cytosolic isozyme (s-GOT), and had a weak sensitivity to glutarate $(36 \%$ inhibition) like the mammalian mitochondrial isozyme (m-GOT). It was also weakly inhibited $(21 \%)$ by fumarate, which was not effective for both of the mammalian isozymes.

In transamination between L-aspartate and $\alpha$-ketoglutarate, mammalian isozymes are inhibited by the latter substrate at higher concentrations. ${ }^{20)}$ Thus, reciprocal velocities were

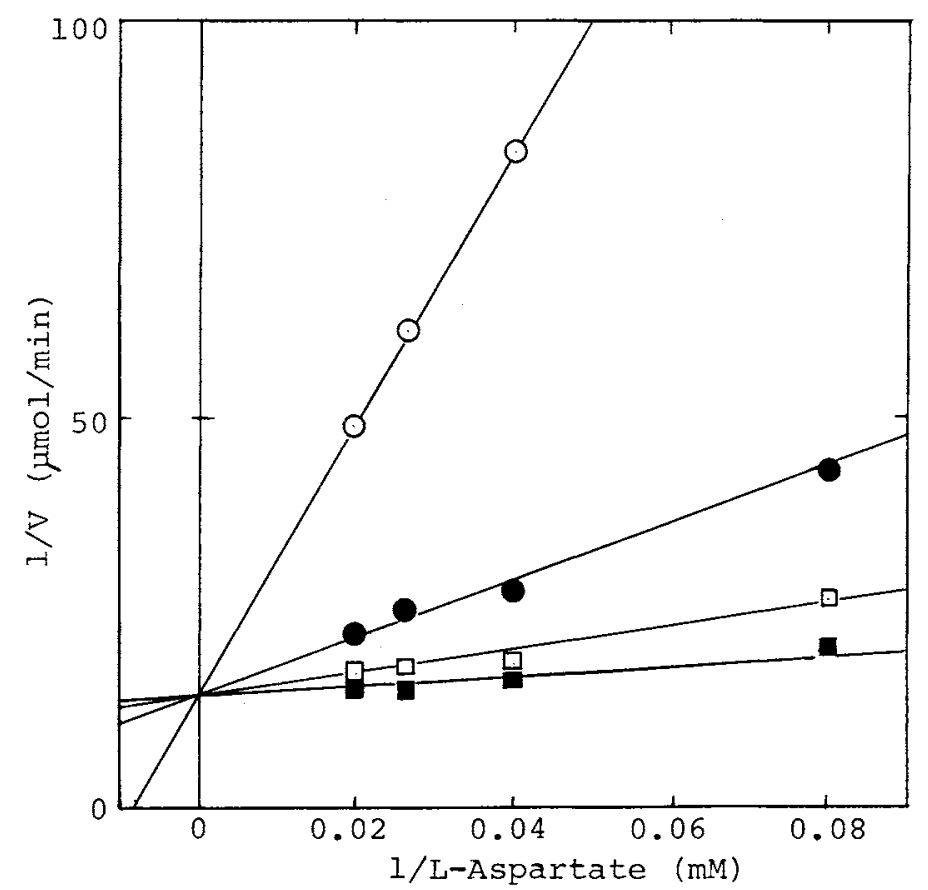

Fig. 2. Effects of $\alpha$-Ketoglutarate Concentration on the Transamination Activity of AAT.

Reciprocal velocities were plotted against the reciprocal concentration of L-aspartate at various fixed levels of $\alpha$-ketoglutarate: $O, 10 \mathrm{~mm} ; 0,5 \mathrm{~mm} \square, 2.5 \mathrm{~mm} ; \square, 1.25 \mathrm{~mm}$. 
plotted against the reciprocal concentrations of L-aspartate at various fixed levels of $\alpha$ ketoglutarate. Figure 2 shows a typical linear competitive inhibition by $x$-ketoglutarate against transamination on L-aspartate as variable substrates, indicating the formation of a dead-end $\alpha$-ketoglutarate-enzyme complex.

\section{Discussion}

In methanogens, the presence of AAT was first demonstrated using anaerobically prepared cell-free extracts of $M$. barkeri (formate-nonutilizing mesophile) and $M$. thermoautotrophicum (formate-nonutilizing thermophile). ${ }^{8)}$ Unlike most enzymes in methanogens, AAT of strain SF-4 (formate-utilizing thermophile) could be assayed under aerobic conditions, suggesting its stability against exposure to oxygen. A reasonable recovery yield of the activity even after several steps of purification also reflects the aerotolerance of the enzyme. On the other hand, the specific activity of purified preparation ( 8.44 units $/ \mathrm{mg}$ ) on L-aspartate was lower than those reported for the other bacterial AATs such as from $E$. coli B (200.0 units/mg) $/$ ) $^{5}$ and Pseudomonas striata (73.1 units/mg). ${ }^{7}$ ) The enzyme protein of strain SF-4 was regarded to be poorly homologous to the above bacterial enzymes on the basis of its molecular size and structure as discussed in the following sections. Thus, the lower specific activity possibly depended on the molecular activity characteristic for this bacterial enzyme.

AAT is well known to have oligomeric molecular structure consisting of two identical subunits. Unexpectedly, this study found that AAT of strain SF-4 had the molecular structure with a monomeric polypeptide quite unusual for this enzyme. The molecular weight $(50,000-57,000)$ itself was lower than those of native enzymes of $E$. coll $\mathrm{B}$ and Pseudomonas striata $(80,000-84,000)$ described above. In the other aminotransferases, pig heart branchedchain amino acid aminotransferase (EC 2.6.1.42) ${ }^{17)}$ and rat liver cysteine aminotrans- ferase $(\mathrm{EC} 2.6 .1 .3)^{18}$ ) are also suggested to exist as monomers with the molecular weights of 75,000 and 84,000 , respectively. On the other hand, various studies on the dimeric AATs have shown that each subunit has a basic catalytic ability but the enzymatic activity seriously depends on a functional interaction between two active sites in the associated form of subunits. ${ }^{21-24)}$ This should indicate that the structure and function of active site region is not homologous between AAT of strain SF-4 and the others. In this sense, it is noteworthy that the absorption spectrum of AAT of strain SF-4 was in agreement with those of the above monomeric aminotransferases ${ }^{17.18)}$ rather than the typical dimeric AATs of bacterial ${ }^{5)}$ and mammalian ${ }^{25}$ origin.

Bacterial AATs are similar in amino donor specificity in that both of $E$. coli AAT and Pseudomonas AAT can weakly react with $\mathrm{L}$ phenylalanine and less with L-tyrosine in addition to L-glutamate and L-aspartate. ${ }^{5.7)}$ They are also active on L-cysteinesulfinate ${ }^{26)}$ but different in the reactivity on L-tryptophan. AAT of strain SF-4 had an amino donor specificity similar to those of the above bacterial species except that it could react weakly with L-cysteine. So far transamination activity on L-cysteine was found only in pig tissues and rat liver. ${ }^{27.28)}$ Ip et al. ${ }^{18)}$ indicated the presence of cysteine aminotransferase (EC 2.6.1.3) by isolating and purifying it from rat liver to apparent homogeneity. Ubuka et al. ${ }^{29.30)}$ could also purify the enzyme from rat liver mitochondria but ultimately attributed it to the action of rat liver mitochondrial aspartate aminotransferase. Our study is the first report of bacterial AAT with an apparent activity on L-cysteine.

With respect to the mechanism of transamination, formation of a dead-end $x$-ketoglutarate-enzyme complex was consistent with a Ping Pong $\mathrm{Bi} \mathrm{Bi}$ mechanism that was demonstrated for the transamination of pig heart AAT isozymes. ${ }^{20}$ ) On the contrary, the inhibitory effects of various dicarboxylic acids again distinguished the enzyme of strain SF-4 
from both of the above mammalian isozymes. In the other aspect, AAT of strain SF-4 may be discussed as the enzyme of a thermophilic bacterium. The optimum temperature and heat stability were observed in the higher temperature range as expected. Recently, a complete amino acid sequence was proposed for the enzyme of $E$. coli $\mathrm{B}^{14)}$ giving rise to $39 \%$ and $40 \%$ homology to mammalian s$\mathrm{GOT}^{15}$ and $\mathrm{m}$-GOT, ${ }^{16)}$ respectively, while AAT of strain SF-4 showed a characteristic amino acid composition, suggesting its lower homology to each of the above mesophilic enzymes. The fact should partly reflect increased reactivity and stability of the enzyme at higher temperatures as well as its properties observed in the molecular structure and substrate specificity. It is of interest to analyze the amino acid sequence of the enzyme which would probably give us information on the evolutionary relationship of AAT from the methanogen belonging to Archaebacteria.

\section{References}

1) D. Rudman and A. Meister, J. Biol. Chem., 200, 591 (1953).

2) J. Pelmont and S. Chesne, Biochimie, 55, 237 (1973).

3) C. Mavrides and W. Orr, J. Biol. Chem., 250, 4128 (1975).

4) J. F. Morrison and J. T. Powell, Eur. J. Biochem., 87, 391 (1978).

5) T. Yagi, H. Kagamiyama, K. Motosugi, M. Nozaki and K. Soda, FEBS Lett., 100, 81 (1979).

6) T. Yagi, H. Kagamiyama, M. Nozaki and K. Soda, Methods Enzymol., 113, 83 (1985).

7) T. Yagi, M. Toyosato and K. Soda, FEBS Lett., 61, 34 (1976).

8) W. R. Kenealy, T. E. Thompson, K. R. Schubert and J. G. Zeikus, J. Bacteriol., 150, 1357 (1982).

9) K. Yamamoto, A. Tachibana, T. Tanaka, M. Taniguchi and S. Oi, Agric. Biol. Chem., 53, 533 (1989).
10) S. Reitman and S. Frankel, Am. J. Clin. Path., 28, 56 (1957)

11) T. W. Goodwin and R. A. Morton, Biochem. J., 40, 628 (1946).

12) U. K. Laemmli, Nature (London), 227, 680 (1970).

13) M. M. Bradford, Anal. Biochem., 74, 248 (1976).

14) K. Kondo, S. Wakabayashi, T. Yagi and H. Kagamiyama, Biochem. Biophys. Res. Commun., 122, 62 (1984).

15) Yu. A. Ovchinnikov, C. A. Egorov, N. A. Aldanova, M. Yu. Feigina, V. M. Lipkin, N. G. Abdulaev, E. V. Grishin, A. P. Kiselev, N. N. Modyanov, A. E. Braunstein, O. L. Polyanovsky and V. V. Nosikov, FEBS Lett., 29, 31 (1973).

16) H. Kagamiyama, R. Sakakibara, S. Tanase, Y. Morino and H. Wada, J. Biol. Chem., 255, 6153 (1980).

17) R. T. Taylor and W. T. Jenkins, J. Biol. Chem., 241, 4396 (1966).

18) M. P. C. Ip, R. J. Thibert and D. E. Schmidt, Jr., Can. J. Biochem., 55, 958 (1977).

19) C. M. Michuda and M. Martinez-Carrion, J. Biol. Chem., 245, 262 (1970).

20) C. P. Henson and W. W. Cleland, Biochemistry, 3, 338 (1964).

21) V. V. Borisov, S. N. Borisova, G. S. Kachalova, N. I. Sosfenov, B. K. Vainshtein, Yu. M. Torchinsky and A. E. Braunstein, J. Mol. Biol., 125, 275 (1978).

22) G. Eichele, G. C. Ford, M. Glov, J. N. Jansonius, C. Mavrides and P. Christein, J. Mol. Biol., 133, 161 (1979)

23) M. Arrio-Dupont and P. R. Coulet, Biochem. Biophys. Res. Commun., 89, 345 (1979).

24) M. Arrio-Dupont and D. Verge, J. Mol. Biol., 157, 383 (1982).

25) A. E. Braunstein, "The Enzymes," Vol. 9, Part B, ed. by P. D. Boyer, Academic Press, New York, 1973 , pp. $379-481$.

26) T. Yagi, H. Kagamiyama and M. Nozaki, Biochem. Biophys. Res. Commun., 90, 447 (1979).

27) P. S. Cammarata and P. P. Cohen, J. Biol. Chem., 187, $439(1950)$.

28) A. Meister, P. E. Fraser and S. V. Tice, J. Biol. Chem., 206, 561 (1954).

29) T. Ubuka, S. Umemura, $Y$. Ishimoto and $M$. Shimomura, Physiol. Chem. Phys., 9, 91 (1977).

30) T. Ubuka, S. Umemura, S. Yuasa, M. Kinuta and K. Watanabe, Physiol. Chem. Phys., 10, 483 (1978). 